\title{
Relationship between personal factors and marketing mix satisfaction of the tourists at Don Hoi Lot in Samutsongkham province, Thailand
}

\author{
Rumpapak Luekveerawattana'*
}

Suan Sunandha Rajabhat University, Thailand

\author{
Keywords: \\ Satisfaction \\ Marketing mix \\ Don Hoi Lot
}

Received: 29 March 2016

Accepted: 16 April 2016

Published: 21 June 2016

\begin{abstract}
This research work aims to investigate the satisfaction of the tourists towards the marketing mix of Don Hoi Lot tourist attraction in SamutSongkham and to identify the relationship between the personal factors of the tourists and the satisfaction towards the marketing mix at Don Hoi Lot tourist attraction in SamutSongkham. The research tools were sets of questionnaires. The samples included 400 tourists at Don Hoi Lord tourist attraction in SamutSongkham. For data analysis, percentage, mean, standard deviation, and Chi Square were used to find the relationship of the independent variables based on a hypothesis. The significant level was limited at 0.05. Most of the tourists were female, 224 in total (56\%). There was no relationship of sex and satisfaction with price, product, location and marketing, There was positive relationship of age and satisfaction with price, product, location and marketing. It is suggested that the administrator of Don Hoi Lot tourist attraction should consider the age factor and improve the location, marketing promotion, the product, and the price in order to reach the target group due to the medium satisfaction level. The administrator should find an approach to increase the satisfaction level such as improving the natural landscape and providing more shaded parking space.
\end{abstract}

(C) 2016 The Author(s). Published by TAF Publishing.

\section{INTRODUCTION}

Don Hoi Lot is a natural tourist attraction in Samut Songkham. There are tourists visiting at all times, especially during the holidays when the number of tourists is greater than normal days. Don Hoi Lot is a famous attraction in Samut Songkham in that there are a number of worm shells living in the area and that the landscape is uniquely spectacular. The area is normally flooded during

*Corresponding author: Rumpapak Luekveerawattana

E-mail: sirittt@yahoo.com the high tide and when the water decreases, the worm shell habitat appears to be taking over a large area of the shore (http://maeklongtoday.com). In addition, Krom Luang Chumphon Shrine in Moo 4, Bang JaKreng subdistrict, Muang district. The shrine is a worship place for the people and highly respected by the coastal fishermen since it is believed to protect them during the fishing trip. Don Hoi Lot area (worm shell habitat) is full of fresh and dry seafood shops; thus, it attracts tourists who like to buy seafood and those who like to have seafood and enjoy the sea view as well as paying respect to Krom Luang Chumphon Shrine. In addition, Don Hoi Lot is regarded as

C The Author(s). Published by TAF Publishing. This is an Open Access article distributed under a Creative Commons Attribution-NonCommercialNoDerivatives 4.0 International License 
the area with the highest density of worm shells in Thailand. However, due to the large number of tourists, the worm shells are caught to make food, and therefore the number of worm shells is decreasing and does not meet the tourists' needs as seen in the smaller size of worm shells. Moreover, the wrong method of catching worm shells- pouring chalk or caustic soda- causes small worm shells to go up on the surface and get caught. According to the interview with Mr. Tritod Wilailert, the sub-district's chief inspector, he said that some of the restaurants imported the worm shells from the south to make food for tourists due to insufficient amount of worm shells in the area and that the quality and taste of the food did not meet the standards. Therefore, the researcher would like to conduct a study investigating the satisfaction and identifying the relationship between the personal factors of the tourists and the satisfaction towards the marketing mix of Don Hoi Lot tourist attraction in Samutsongkham province. The results can be applied for improvement of the attraction in the future.

\section{Objectives}

1. To investigate the satisfaction of the tourists towards the marketing mix of Don Hoi Lot tourist attraction in SamutSongkham

2. To identify the relationship between the personal factors and the satisfaction towards the marketing mix of Don Hoi Lot tourist attraction in SamutSongkham

\section{Hypotheses}

1. There is a relationship between sex of tourists and satisfaction towards the product

2. There is a relationship between sex of tourists and satisfaction towards the price

3. There is a relationship between sex of tourists and satisfaction towards the location

4. There is a relationship between sex of tourists and satisfaction towards the marketing promotion

5. There is a relationship between sex of tourists and overall satisfaction

6. There is a relationship between age of tourists and satisfaction towards the product

7. There is a relationship between sex of tourists and satisfaction towards the price

8. There is a relationship between sex of tourists and satisfaction towards the location

9. There is a relationship between sex of tourists and satisfaction towards the marketing promotion

10. There is a relationship between sex of tourists and overall satisfaction.

\section{LITERATURE REVIEW}

For most people, marketing means a type of advertisement and a sale promotion; however, as a matter of fact, an advertisement and a sale promotion are the elements of marketing. The reason as to why most people think so is that an advertisement and a sale promotion are more apparent than other elements. Conservative marketers view that the enterprise that produces quality products tends to be successful because consumers will come to buy the products at the source of production; therefore, the manufacturing processes are the important factor. Nowadays, the view has changed; not only are the products of good quality, but the modern marketing activities also fulfill the needs and preferences of the consumers. Therefore, modern marketing promotions, effective distribution methods, product distribution, and products transporting must be carried out appropriately in order to meet the customer's needs. The new marketing activities require collaboration between the production team and the marketing team which aims to best satisfy the consumers (Kotler, 1994:5). The strategic marketing management known as 4ps or marketing mix consists of Product, Price, Place, and Promotion.

\section{Product}

A product is what a business offers to the target customers. It can be objective, known as "product", or subjective, known as "service". Ideally, the product must be designed/ manufactured in order to fulfill the needs of the target group and, in other words, to satisfy the consumers.

\section{Price}

Price is the value of the product in form of money. Appropriate price must be satisfactory to the customers, reflect value, and make profits to the business. Provided that the consumers prefer high-quality products, the price can be set high. On the other hand, provided that the consumers prefer cheap products, the price must be set low to be attractive.

\section{Place/Distribution Channel}

Product distribution can determine the distribution channel and distribute the products to the consumers. The direct distribution channel is to sell the product to the consumers directly. The indirect channel is to sell the products through middlemen such as wholesalers, 
retailers and agency representatives. However, both of the channels can be used at the same time.

\section{Promotion}

Marketing promotion is a marketing communication to inform or to encourage the buying behavior as well as remind the consumers of the products. Marketing promotion can be done by advertising through printed media, broadcasted media outdoor, and words of mouth, all of which encourage sales. Marketing tourism responsibly is the important issue to manage sustainable tourism (Luekveerawattana, 2012:391) so the manager of tourism destination should pay attention to undertake marketing sustainably

\section{Relevant Research}

Dolnicar (2004) conducted a research study on the topic of "Insights into sustainable tourists in Austria: a data-based priori segmentation approach". It was found that the effective and sustainable marketing approach for tourism was to target the tourists who were interested in natural spots with uniqueness and fond of or willing to preserve the nature since they tended to contribute to high expenses and long stay which resulted in good profits. The independent variables investigated in the study were socio-demographic characteristics, occupational category, travel behavior, regional distribution, guest satisfaction, while the dependent variables were sustainability and non-sustainability analyzed by Chi-square and ANOVA test.

Aniah, Eja, Out \& Ushie (2009) conducted a research work on "Patronage of ecotourism potentials as a strategy for sustainable tourism development in Cross River State, Nigeria". They found that despite of facilities available at Obudu Ranch Resort, more facilities were needed to attract national and international tourists. Obudu Ranch Resort was well-known for improving the tourism and the way of life of the people in Cross River State in terms of income and occupational opportunities. Infrastructures such as roads, electricity systems, and tap water systems were built to facilitate the tourists. This research work also investigated the type of tourists visiting Obudu Ranch Resort. It was found that there were both national and international tourists visiting during 2001-2008. The variables studied were satisfaction towards the resort, facilities at the resort, objectives of the visit, and the population in the study area, all of which were analyzed by Chi-square test in order to test the following hypotheses:

H0: There is no significant difference between the number of tourists visiting Obudu Ranch Resort and the distance between Obudu and the tourist's home.

H1: There is significant difference between the number of tourists visiting Obudu Ranch Resort and the distance between Obudu and the tourist's home and rejected Ho's hypothesis.

\section{METHODOLOGY}

The study of comparison between the personal factors of the tourists and the satisfaction towards the marketing mix of Don Hoi Lot in Samut Songkham is a quantitative work conducted using the questionnaires on the tourists who visited Don Hoy Lot, Bang JaKreng sub-district, Muang district, Samut Songkham province. The sample group included 400 tourists (Taro Yamane Table cited in Lohakit: 2005). The objectives are to reveal the demographic information of the tourists and the satisfaction towards the marketing mix and to make an analytical comparison between the personal factors of the tourists and the satisfaction towards the marketing mix of Don Hoi Lot.

The population in the study is the tourists visiting Don Hoi Lot, Bang JaKreng sub-district, Muang district, Samut Songkham province. On average, there are 1,000 tourists a day (Miss UmpaiPuntong, officer at Krom Luang Chumphon Khet Udomsak Foundation). The research tools are the structured questionnaires which are divided into two parts: 1) personal information and 2) satisfaction towards the marketing mix.

\section{STATISTICS USED IN THE ANALYSIS}

1. Percentage and mean are used to describe general information, personal factors, and satisfaction towards the marketing mix of the tourist attraction.

2. Chi-square test is used to identify the relationship between the independent variable based on the hypotheses. The significant level is limited at 0.05 . According to Table 1, it was found 224 (56\%) of the tourists were female, and 176 (44\%) of them were male. In terms of age, 172 tourists (43\%) aged 20-30 years old, followed by 20 tourists (22.5\%) aged 31-40, 87 tourists (21.8) aged 31-40, and 51 tourists (12.7) aged over 40. In terms of educational level, $227(69.3 \%)$ tourists did not have a bachelor degree and 3 tourists (0.7) had a degree over a bachelor degree. In terms of occupation, 138 of them (34.5) were students/college students, 113 of them (28.2) were employees, 73 of them (18.3) were government officers, 54 of them (13.5) were state enterprise employees, and 22 of them (5.5) were business 
owners/others. In terms of monthly income, 172 of them (43\%) earned 8,000-15,000 Baht, 101 of them (25.3\%) earned 15,001-25,000, 69 of them (17.3) earned less than
8,000, 49 of them (12.3) earned 25,001-40,000, and 9 of them $(2.1 \%)$ earned over 40,000 Baht.

TABLE 1. Demographic information of the tourists

\begin{tabular}{lcc}
\hline \hline \multicolumn{1}{c}{ Factor } & Number & Percent \\
\hline Sex & 176 & \\
Male & 224 & 54 \\
Female & & \\
Age & 90 & 22.5 \\
Below 20 & 172 & 43 \\
20-30 & 87 & 21.8 \\
31-40 & 51 & 12.7 \\
Over 40 & & \\
Educational Level & 277 & 69.3 \\
Below bachelor degree & 120 & 30 \\
Bachelor degree & 3 & 0.7 \\
Over bachelor degree & & \\
Occupation & 138 & 34.5 \\
students/college students & 73 & 18.3 \\
government officers & 113 & 28.2 \\
business employees & 54 & 13.5 \\
state enterprise employees & 22 & 5.5 \\
business owners/ others & & \\
Monthly income & 69 & 17.3 \\
Below 8,000 Baht & 172 & 43 \\
8,001-15,000 Baht & 101 & 25.3 \\
15,001-25,000 Baht & 49 & 2.3 \\
25,001-40,000 Baht & & \\
Over 40,000 Baht & & \\
\hline \hline
\end{tabular}

TABLE 2. Satisfaction of the tourists in each aspect

\begin{tabular}{lcccc} 
Factor & Number & Mean & Standard deviation & Satisfaction level \\
\hline Product & 400 & 3.35 & .62 & Medium \\
Price & 400 & 3.35 & .67 & Medium \\
Place & 400 & 3.31 & .58 & Medium \\
Promotion & 400 & 3.27 & .65 & Medium \\
Overall & 400 & 3.32 & .58 & Medium \\
satisfaction & 4.35 &
\end{tabular}

The results showed that the satisfaction of the tourists towards the product, price, place, promotion, and overall satisfaction was in the medium level. Hypothesis 1 :
Relationship between sex and satisfaction Hypothesis 1.1: Relationship between sex and satisfaction towards the product 
TABLE 3. Relationship between sex and satisfaction towards the product

\begin{tabular}{|c|c|c|c|c|c|c|c|c|}
\hline & & \multicolumn{4}{|c|}{ "Satisfaction } & \multirow[t]{2}{*}{ Total } & $\chi^{2}$ & \multirow[t]{2}{*}{ P-value } \\
\hline & & Low & Medium & High & Very high & & & \\
\hline \multirow[t]{2}{*}{ Male } & Number & 17 & 84 & 54 & 21 & 176 & .451 & .930 \\
\hline & Percent & $4.3 \%$ & $21.0 \%$ & $13.5 \%$ & $5.3 \%$ & $44.0 \%$ & & \\
\hline \multirow[t]{2}{*}{ Female } & Number & 25 & 109 & 63 & 27 & 224 & & \\
\hline & Percent & $6.3 \%$ & $27.3 \%$ & $15.8 \%$ & $6.8 \%$ & $56.0 \%$ & & \\
\hline \multirow[t]{2}{*}{ Total } & Number & 42 & 193 & 117 & 48 & 400 & & \\
\hline & Percent & $10.5 \%$ & $48.3 \%$ & $29.3 \%$ & $12.0 \%$ & $100.0 \%$ & & \\
\hline
\end{tabular}

According to the table, there is no relationship between sex and satisfaction towards the product at .05s0ignificant level.
Hypothesis 1.2: Relationship between sex and overall satisfaction towards the price.

TABLE 4. Relationship between sex and overall satisfaction towards the price

\begin{tabular}{|c|c|c|c|c|c|c|c|c|}
\hline & & \multicolumn{4}{|c|}{ Satisfaction } & \multirow[t]{2}{*}{ Total } & $x^{2}$ & \multirow[t]{2}{*}{ P-value } \\
\hline & & Low & Medium & High & Very high & & & \\
\hline \multirow[t]{2}{*}{ Male } & Number & 22 & 86 & 39 & 29 & 176 & .792 & .851 \\
\hline & Percent & $5.5 \%$ & $21.5 \%$ & $9.8 \%$ & $7.2 \%$ & $44.0 \%$ & & \\
\hline \multirow[t]{2}{*}{ Female } & Number & 29 & 102 & 49 & 44 & 224 & & \\
\hline & Percent & $7.2 \%$ & $25.5 \%$ & $12.3 \%$ & $11.0 \%$ & $56.0 \%$ & & \\
\hline \multirow[t]{2}{*}{ Total } & Number & 51 & 188 & 88 & 73 & 400 & & \\
\hline & Percent & $12.8 \%$ & $47.0 \%$ & $22.0 \%$ & $18.3 \%$ & $100.0 \%$ & & \\
\hline
\end{tabular}

According to the table, there is no relationship between sex and satisfaction towards the price at .05 significant level.
Hypothesis 1.3: Relationship between sex and overall satisfaction towards the place.

TABLE 5. Relationship between sex and overall satisfaction towards the place

\begin{tabular}{|c|c|c|c|c|c|c|c|c|}
\hline & & \multicolumn{4}{|c|}{ "Satisfaction } & \multirow[t]{2}{*}{ Total } & $x^{2}$ & \multirow[t]{2}{*}{ P-value } \\
\hline & & Low & Medium & High & Very high & & & \\
\hline \multirow[t]{2}{*}{ Male } & Number & 23 & 85 & 57 & 11 & 176 & .483 & .923 \\
\hline & Percent & $5.8 \%$ & $21.3 \%$ & $14.2 \%$ & $2.8 \%$ & $44.0 \%$ & & \\
\hline \multirow[t]{2}{*}{ Female } & Number & 32 & 106 & 75 & 11 & 224 & & \\
\hline & Percent & $8.0 \%$ & $26.5 \%$ & $18.8 \%$ & $2.8 \%$ & $56.0 \%$ & & \\
\hline \multirow[t]{2}{*}{ Total } & Number & 55 & 191 & 132 & 22 & 400 & & \\
\hline & Percent & $13.8 \%$ & $47.8 \%$ & $33.0 \%$ & $5.5 \%$ & $100.0 \%$ & & \\
\hline
\end{tabular}

According to the table, there is no relationship between sex and satisfaction towards the place at .05 significant level.
Hypothesis: 1.4 Relationship between sex and satisfaction towards the promotion. 
TABLE 6. Relationship between sex and satisfaction towards the promotion

\begin{tabular}{llrrrrrrr}
\hline \hline & & \multicolumn{2}{c}{ Satisfaction } & & Total & $\chi^{2}$ & P-value \\
\hline Male & Number & \multicolumn{1}{c}{ Low } & Medium & High & Very high & & & \\
& Percent & $7.0 \%$ & 28 & 34 & 32 & 176 & 7.466 & .058 \\
Female & Number & 37 & 105 & $8.5 \%$ & $8.0 \%$ & $44.0 \%$ & & \\
& Percent & $9.3 \%$ & $26.3 \%$ & $15.0 \%$ & $5.5 \%$ & $56.0 \%$ & & \\
Total & Number & 65 & 187 & 94 & 54 & 400 & & \\
& Percent & $16.3 \%$ & $46.8 \%$ & $23.5 \%$ & $13.5 \%$ & $100.0 \%$ & & \\
\hline \hline
\end{tabular}

According to the table, there is no relationship between sex and satisfaction towards the promotion at.05 significant level. Hypothesis: 1.5 Relationship between sex and overall satisfaction.

TABLE 7. Relationship between sex and overall satisfaction

\begin{tabular}{|c|c|c|c|c|c|c|c|c|}
\hline & & \multicolumn{4}{|c|}{ Satisfaction } & \multirow[t]{2}{*}{ Total } & $\gamma^{2}$ & \multirow[t]{2}{*}{ P-value } \\
\hline & & Low & Medium & High & Very high & & & \\
\hline \multirow[t]{2}{*}{ Male } & Number & 16 & 89 & 51 & 20 & 176 & 2.333 & .506 \\
\hline & Percent & $4.0 \%$ & $22.3 \%$ & $12.8 \%$ & $5.0 \%$ & $44.0 \%$ & & \\
\hline \multirow[t]{2}{*}{ Female } & Number & 28 & 106 & 71 & 19 & 224 & & \\
\hline & Percent & $7.0 \%$ & $26.5 \%$ & $17.8 \%$ & $4.8 \%$ & $56.0 \%$ & & \\
\hline \multirow[t]{2}{*}{ Total } & Number & 44 & 195 & 122 & 39 & 400 & & \\
\hline & Percent & $11.0 \%$ & $48.8 \%$ & $30.5 \%$ & $9.8 \%$ & $100.0 \%$ & & \\
\hline
\end{tabular}

According to the table, there is no relationship between sex and overall satisfaction at .05 significant level.
Hypothesis 2: Relationship between age and satisfaction. Hypothesis 2.1: Relationship between age and satisfaction towards the product.

TABLE 8. Relationship between age and satisfaction towards the product

\begin{tabular}{|c|c|c|c|c|c|c|c|c|}
\hline & & \multicolumn{4}{|c|}{ Satisfaction } & \multirow[t]{2}{*}{ Total } & & \multirow{2}{*}{$\begin{array}{c}\text { P- } \\
\text { value } \\
\end{array}$} \\
\hline & & Low & Medium & High & Very high & & & \\
\hline \multirow[t]{2}{*}{ Below 20} & Number & 2 & 49 & 27 & 12 & 90 & 27.426 & .001 \\
\hline & Percent & $0.5 \%$ & $12.3 \%$ & $6.8 \%$ & $3.0 \%$ & $22.5 \%$ & & \\
\hline \multirow[t]{2}{*}{$20-30$} & Number & 32 & 74 & 49 & 17 & 172 & & \\
\hline & Percent & $8.0 \%$ & $18.5 \%$ & $12.3 \%$ & $4.3 \%$ & $\begin{array}{r}43.0 \% \\
87\end{array}$ & & \\
\hline $31-40$ & Percent & $2.0 \%$ & $10.0 \%$ & $6.3 \%$ & $3.5 \%$ & $21.8 \%$ & & \\
\hline \multirow[t]{2}{*}{ Over 40} & Number & 0 & 30 & 16 & 5 & 51 & & \\
\hline & Percent & $.0 \%$ & $7.5 \%$ & $4.0 \%$ & $1.3 \%$ & $12.8 \%$ & & \\
\hline \multirow[t]{2}{*}{ Total } & Number & 42 & 193 & 117 & 48 & 400 & & \\
\hline & Percent & $10.5 \%$ & $48.3 \%$ & $29.3 \%$ & $12.0 \%$ & $100.0 \%$ & & \\
\hline
\end{tabular}

According to the table, there is no relationship between age and satisfaction towards the product at .001 significant level.
Hypothesis 2.2: Relationship between age and satisfaction towards the price. 
TABLE 9. Relationship between age and satisfaction towards the price

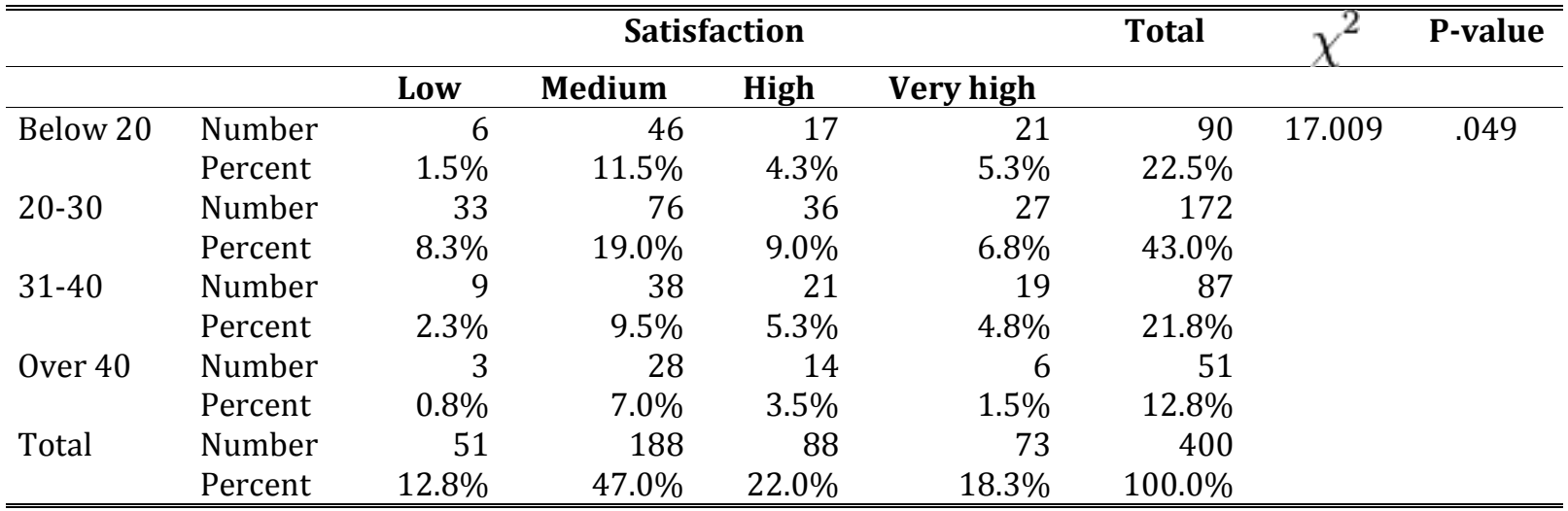

According to the table, there is no relationship between age and satisfaction towards the price at .049 significant level.
Hypothesis 2.3: Relationship between age and satisfaction towards the place.

TABLE 10. Relationship between age and satisfaction towards the place

\begin{tabular}{|c|c|c|c|c|c|c|c|c|}
\hline & & \multicolumn{4}{|c|}{ Satisfaction } & \multirow[t]{2}{*}{ T"Total } & \multirow[t]{2}{*}{$\chi^{2}$} & \multirow[t]{2}{*}{ P-value } \\
\hline & & Low & Medium & High & Very high & & & \\
\hline Below & Number & 5 & 52 & 27 & 6 & 90 & 35.471 & .000 \\
\hline 20 & Percent & $1.3 \%$ & $13.0 \%$ & $6.8 \%$ & $1.5 \%$ & $22.5 \%$ & & \\
\hline \multirow[t]{2}{*}{$20-30$} & Number & 41 & 70 & 56 & 5 & 172 & & \\
\hline & Percent & $10.3 \%$ & $17.5 \%$ & $14.0 \%$ & $1.3 \%$ & $43.0 \%$ & & \\
\hline \multirow[t]{2}{*}{$31-40$} & Number & 9 & 38 & 33 & 7 & 87 & & \\
\hline & Percent & $2.3 \%$ & $9.5 \%$ & $8.3 \%$ & $1.8 \%$ & $21.8 \%$ & & \\
\hline \multirow[t]{2}{*}{ Over 40} & Number & 0 & 31 & 16 & 4 & 51 & & \\
\hline & Percent & $.0 \%$ & $7.8 \%$ & $4.0 \%$ & $1.0 \%$ & $12.8 \%$ & & \\
\hline \multirow[t]{2}{*}{ Total } & Number & 55 & 191 & 132 & 22 & 400 & & \\
\hline & Percent & $13.8 \%$ & $47.8 \%$ & $33.0 \%$ & $5.5 \%$ & $100.0 \%$ & & \\
\hline
\end{tabular}

According to the table, there is no relationship between age and satisfaction towards the place at .000 significant level.
Hypothesis 2.4: Relationship between age and satisfaction towards the promotion.

TABLE 11. Relationship between age and satisfaction towards the promotion

\begin{tabular}{|c|c|c|c|c|c|c|c|c|}
\hline & & \multicolumn{4}{|c|}{ Satisfaction } & \multirow[t]{2}{*}{ Total } & \multirow{2}{*}{$\chi^{2}$} & \multirow[t]{2}{*}{ P-value } \\
\hline & & Low & Medium & High & Very high & & & \\
\hline \multirow[t]{2}{*}{ Below 20} & Number & 5 & 50 & 18 & 17 & 90 & 30.885 & .000 \\
\hline & Percent & $1.3 \%$ & $12.5 \%$ & $4.5 \%$ & $4.3 \%$ & $22.5 \%$ & & \\
\hline \multirow{2}{*}{$20-30$} & Number & 43 & 75 & 36 & 18 & 172 & & \\
\hline & Percent & $10.8 \%$ & $18.8 \%$ & $9.0 \%$ & $4.5 \%$ & $43.0 \%$ & & \\
\hline \multirow[t]{2}{*}{$31-40$} & Number & 16 & 35 & 23 & 13 & 87 & & \\
\hline & Percent & $4.0 \%$ & $8.8 \%$ & $5.8 \%$ & $3.3 \%$ & $21.8 \%$ & & \\
\hline \multirow[t]{2}{*}{ Over 40} & Number & 1 & 27 & 17 & 6 & 51 & & \\
\hline & Percent & $0.3 \%$ & $6.8 \%$ & $4.3 \%$ & $1.5 \%$ & $12.8 \%$ & & \\
\hline \multirow[t]{2}{*}{ Total } & Number & 65 & 187 & 94 & 54 & 400 & & \\
\hline & Percent & $16.3 \%$ & $46.8 \%$ & $23.5 \%$ & $13.5 \%$ & $100.0 \%$ & & \\
\hline
\end{tabular}


According to the table, there is no relationship between age and satisfaction towards the promotion at .000 significant level.

Hypothesis 2.5: Relationship between age and overall satisfaction.
According to the table, there is no relationship between age and overall satisfaction towards the product at .000 significant level.

TABLE 12. Relationship between age and overall satisfaction

\begin{tabular}{|c|c|c|c|c|c|c|c|c|}
\hline & & \multicolumn{4}{|c|}{ Overall satisfaction } & \multirow[t]{2}{*}{ Total } & $\gamma^{2}$ & \multirow[t]{2}{*}{ P-value } \\
\hline & & Low & Medium & High & Very high & & & \\
\hline \multirow[t]{2}{*}{ Below 20} & Number & 1 & 52 & 25 & 12 & 90 & 35.131 & .000 \\
\hline & Percent & $0.3 \%$ & $13.0 \%$ & $6.3 \%$ & $3.0 \%$ & $22.5 \%$ & & \\
\hline \multirow[t]{2}{*}{$20-30$} & Number & 34 & 75 & 51 & 12 & 172 & & \\
\hline & Percent & $8.5 \%$ & $18.8 \%$ & $12.8 \%$ & $3.0 \%$ & $43.0 \%$ & & \\
\hline \multirow[t]{2}{*}{$31-40$} & Number & 9 & 38 & 28 & 12 & 87 & & \\
\hline & Percent & $2.3 \%$ & $9.5 \%$ & $7.0 \%$ & $3.0 \%$ & $21.8 \%$ & & \\
\hline \multirow[t]{2}{*}{ Over 40} & Number & 0 & 30 & 18 & 3 & 51 & & \\
\hline & Percent & $.0 \%$ & $7.5 \%$ & $4.5 \%$ & $0.8 \%$ & $12.8 \%$ & & \\
\hline \multirow[t]{2}{*}{ Total } & Number & 44 & 195 & 122 & 39 & 400 & & \\
\hline & Percent & $11.0 \%$ & $48.8 \%$ & $30.5 \%$ & $9.8 \%$ & $100.0 \%$ & & \\
\hline
\end{tabular}

\section{CONCLUSION AND SUGGESTIONS}

Most of the tourists were females, 224 in total (56\%). The 172 of them (43\%) were aged between 20 and 30. The 277 of the tourists (69.3\%) had an educational level below a bachelor degree, and 138 of them (34.5\%) were students. In addition, 172 of them (43\%) earned 8,000-15,000 Baht income per month. The satisfaction of the tourists towards the product, price, place, promotion, and overall satisfaction was in the medium level. According to the hypothesis testing, it was found that there was a relationship between age and satisfaction of the tourists towards the product, price, place and promotion at .05 significant level. In addition, the tourists suggested that the landscape and the sidewalk be improved and that the shops not be located on the sidewalk. Moreover, they suggested that the road be cleaned once a week and expanded. The tourists also voiced that the shops were too adjacent and there was lack of variety of foods.

\section{REFERENCES}

Aniah, E.J., Eja, E.I., Otu, J.E., \& Ushie, M.A. 2009. Patronage of ecotourism potentials as a strategy for sustainable tourism development in Cross River State, Nigeria. Journal Of Geography \& Geology, 1(2): 20-27.

Dolnicar, S. 2004. Insights into sustainable tourists in Austria: A data-based a priori segmentation approach. Journal of Sustainable Tourism, 12(3): 209-218. DOI: 10.1080/09669580408667234

Kotler, P. 1994. Marketing management: Analysis, planning, implementation, and control. New Jersey, NJ: PrenticeHall.

Lohakit, S. 2005. Smoking attitude of Chiang Mai University and Mea Jo University freshmen data analysis. M.Sc. thesis, Department of Statistics, Chiang Mai University, Chiang Mai, Thailand.

Luekveerawattana, S. 2012. Cultural landscape for sustainable tourism case study of Amphawa community. ProcediaSocial \& Behavioral Sciences, 65: 387-396. D0I: 10.1016/j.sbspro.2012.11.139

Wilailert, T. (2015, December 22). Personal interview.

$$
\text { — This article does not have any appendix. - }
$$

